\title{
Anastomosing reach control on hydraulics and sediment distribution on the Sabie River, South Africa
}

\author{
NEIL ENTWISTLE ${ }^{1}$, GEORGE HERITAGE ${ }^{2}$, STEPHEN TOOTH ${ }^{3} \&$ \\ DAVID MILAN ${ }^{4}$ \\ 1 University of Salford, Peel Building, University of Salford, Salford M5 4WT, UK \\ n.s.entwistle@salford.ac.uk \\ 2 AECOM. Exchange Court, 1 Dale Street, Liverpool L2 2ET, UK \\ 3 Department of Geography and Earth Sciences, Aberystwyth University, Llandinam Building, Penglais Campus, \\ Aberystwyth $S Y 233 D B, U K$ \\ 4 Department of Geography, Environment and Earth Sciences, University of Hull, Cottingham Road, Hull, HU6 7RX, UK
}

\begin{abstract}
Rivers in the Kruger National Park, South Africa, have variable degrees of bedrock and alluvial influence. Pre-2000 aerial imagery for the Sabie River (catchment area $6320 \mathrm{~km}^{2}$ ) reveals downstream alternations from alluvial single thread or braided, to bedrock anastomosed or mixed anastomosed channel types, with pool-rapids also present locally. In 2000 and 2012, extreme floods resulted in significant alluvial erosion, widely exposing the underlying bedrock. Since the 2012 flood, aerial LiDAR surveys reveal the strong gradient control exerted by the bedrock and mixed anastomosed channel types, which influences hydraulic conditions and sediment dynamics. Two dimensional hydraulic modelling of moderate floods $\left(<1500 \mathrm{~m}^{3} \mathrm{~s}^{-1}\right)$ reveals reduced velocities upstream of bedrock or mixed anastomosed channel types, which promotes deposition. During more extreme floods $\left(>3500 \mathrm{~m}^{3} \mathrm{~s}^{-1}\right)$, the bedrock or mixed anastomosed channel types are drowned out, resulting in dramatically increased velocities along the entire river and widespread alluvial stripping regardless of initial channel type or location.
\end{abstract}

Key words semi-arid river; 2D modelling; anastomosing channels; flood impact; Sabie River, South Africa

\section{BACKGROUND}

Many of the large rivers draining southern Africa are characterised by incised bedrock 'macrochannels' cut 10-20 m into ancient planation surfaces, but with variable amounts of unconsolidated alluvial sediment infill. Variations in lithology, structure, flow regime, sediment supply and vegetation assemblages have created morphologically-diverse river systems, many of which have been characterised by extended periods of alluviation on an historic or longer timescale. This has led to the development of an increasingly alluviated set of channel types that commonly mask the underlying bedrock. Alluviation is periodically interrupted by extreme flood 'stripping' of accumulated alluvium and these events have been highlighted as an important mechanism leading to fluvial change and system 'resetting' in African, Australian, Indian and North American river systems (Heritage et al., 2001; Kale et al., 1996; Nanson, 1986). Heritage et al. (2004) suggested that channel response to extreme floods is more complex than indicated by these simple stripping models, with reach-scale responses possibly being related to factors such as channel style, flood sequencing and local geology. This paper presents additional evidence from two significant cyclone-driven flood events (2000 and 2012) that have impacted on the Sabie River, South Africa, and which illustrate the controlling role of bedrock anastomosing and mixed anastomosing channel reaches in influencing the pattern of alluvial sediment loss and gain.

\section{CHARACTERISTICS OF THE STUDY RIVER}

The Sabie River drains a $6320 \mathrm{~km}^{2}$ semi-arid catchment in Mpumalanga Province, South Africa (Fig. 1(a)). It rises in the Drakensberg Mountains to the west (1600 m a.s.1.) and descends rapidly onto the low-relief Lowveld (400 m a.s.l.) and Lebombo zones (200 m a.s.l.) in the east. On average, rainfall is greater in the highland areas $(2000 \mathrm{~mm} /$ year $)$ and declines rapidly towards the South Africa-Mozambique border $\left(450 \mathrm{~mm} /\right.$ year). Average winter discharges are $3-5 \mathrm{~m}^{3} \mathrm{~s}^{-1}$, summer wet season base flows are $15-20 \mathrm{~m}^{3} \mathrm{~s}^{-1}$, with a mean annual maximum of $289 \mathrm{~m}^{3} \mathrm{~s}^{-1}$. Sediment load consists predominantly of granule-pebble gravel and sand (Rogers and O'Keefe 2003). Cenozoic river incision has created a wide bedrock macrochannel (van Niekerk et al., 

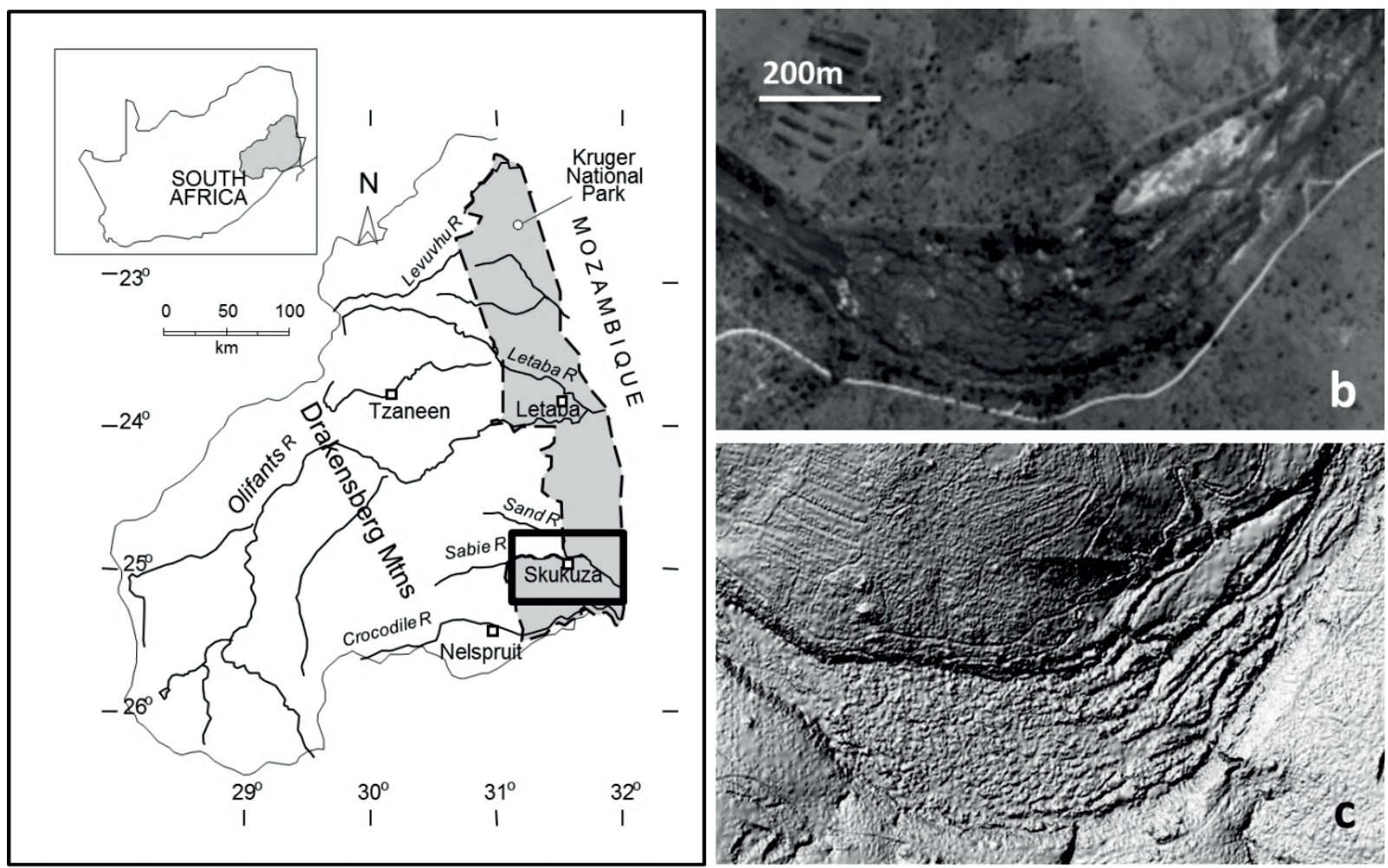

Fig. 1 (a) Location of the Sabie River, Mpumalanga Province, South Africa, and character of a mixed anastomosed reach on the river identified from (b) aerial imagery and (c) LIDAR DEM. Flow direction is from middle left to upper right.

1995), which hosts a variety of channels, alluvial sedimentary features, and riparian vegetation. The degree of bedrock influence varies along the river as a function of the geology (Cheshire, 1994) resulting in a variable fluvial geomorphology. Among the more notable bedrock-influenced features exhibited by the river are reaches of bedrock anastomosed or mixed anastomosed channels that divide and rejoin around bedrock and alluvial islands (Fig. 1(b) and (c)).

\section{ANASTOMOSING REACH CONTROL ON CHANNEL SEDIMENTOLOGY AND HYDRAULICS}

Prior to the cyclone-driven flood of 2000 the Sabie River displayed a strongly alluviated state (Heritage et al., 2001). Classification of the channel types present (Fig. 2) reveals a diverse but well-ordered set of channel types with alluviated channel segments (single thread, braided) tending to form upstream of bedrock anastomosing and mixed anastomosing channels.

Interrogation of aerial LIDAR data collected following the 2000 and 2012 floods on the river provides information on the gradients through the anastomosed reaches (Fig. 3). Measurement of

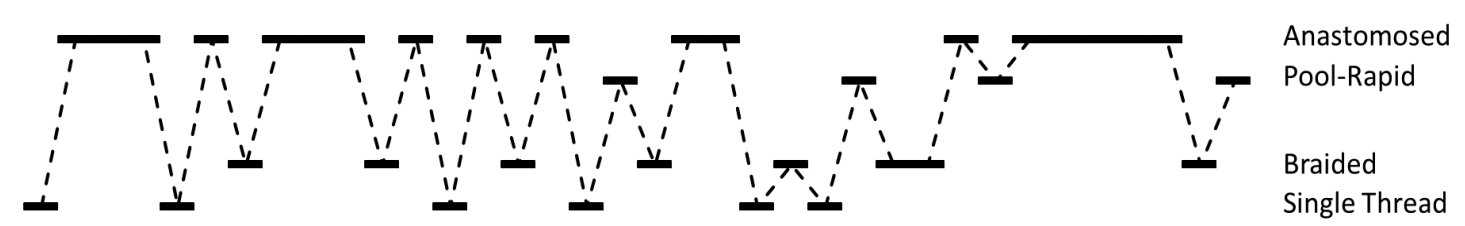

Channel Reach Sequence

Fig. 2 Channel type variation exhibited over a $106 \mathrm{~km}$ length of the Sabie River prior to the extreme flood of January 2000 ( $1=$ most upstream reach type, $36=$ most downstream reach type). The 'anastomosed' category includes both bedrock anastomosed and mixed anastomosed types. 


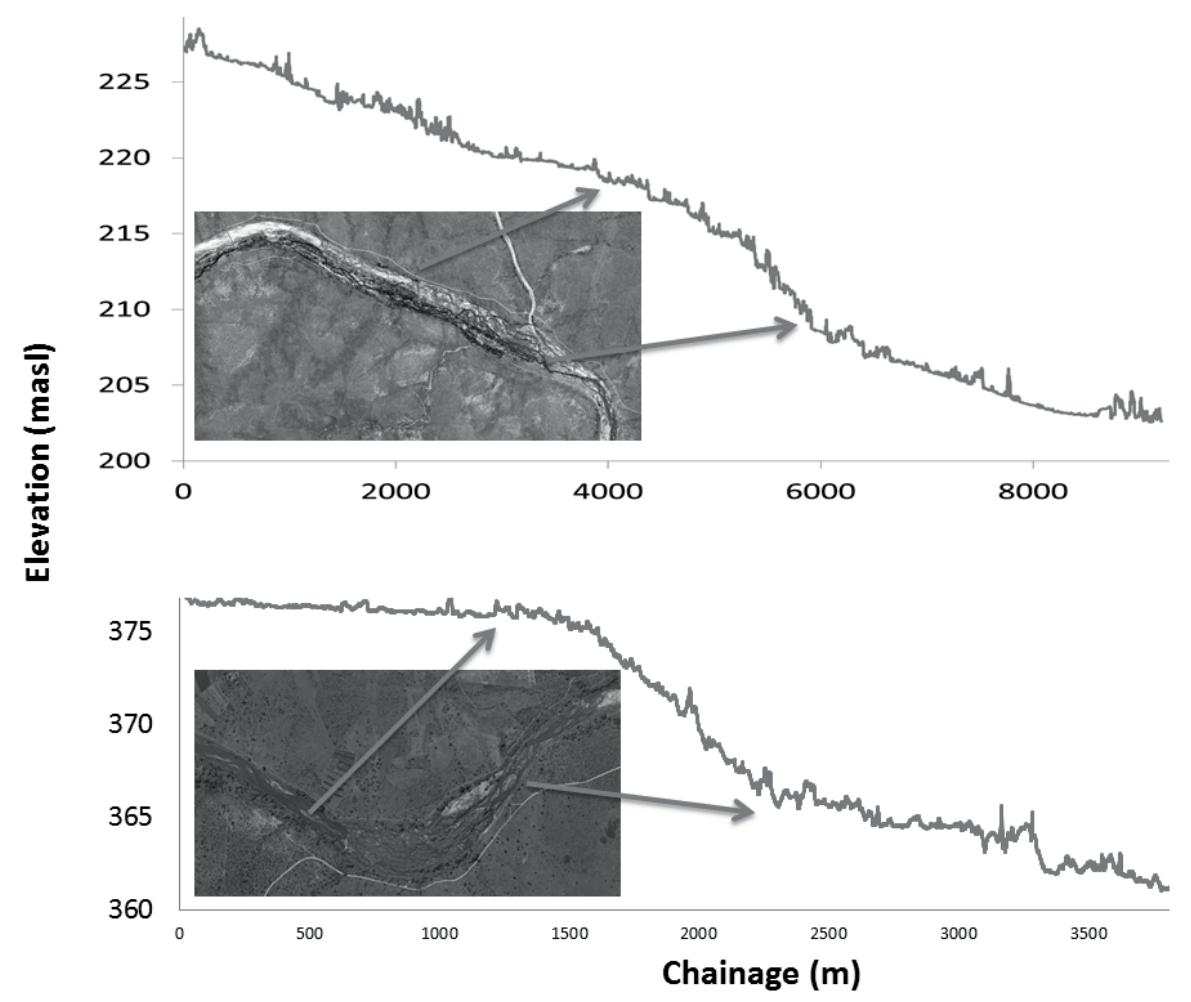

Fig. 3 Example LIDAR long profiles from bedrock or mixed anastomosed reaches of the Sabie River. Limits of the anastomosed reaches are indicated by arrows with more alluviated reaches occurring along the reduced gradient reaches upstream and downstream

reach gradients suggests some variability around a mean of 0.0044 (std dev. 0.0029). This compares with the lower, less variable, alluvial reach mean gradient of 0.0013 (std dev. 0.00047). These values are comparable with reach gradients measured by Heritage et al. (2003) using dGPS survey equipment.

LiDAR data for the Sabie River were also used in the simulation of flood hydraulics. Fifty kilometres of the channel were flown, covering approximately 15600 hectares and generating around 150 million ground points at an average density of 409318 points per $\mathrm{km}^{2}$. These data were stripped of vegetation and gridded at $2-\mathrm{m}$ resolution to create a digital elevation model (DEM) for use in 2D flow modelling. Horitt and Bates (2002) note that many of the roughness factors represented by the roughness coefficient in 1D models are integrated into the modelling process in 2D models. As such, a base Mannings $n$ roughness value of 0.03 was used in a JFLOW 2D depth-averaged flow model, with roughness variation then represented by topographic variation in the DEM. JFLOW is a commercial flow model noted for its ability to handle large data sets through the use of a graphics processing unit (GPU) based computation. This allowed the river to be modelled as 13 connected reaches across a range of flows up to $5000 \mathrm{~m}^{3} \mathrm{~s}^{-1}$.

Model results for moderate $\left(1500 \mathrm{~m}^{3} \mathrm{~s}^{-1}\right)$ to extreme flows $\left(5000 \mathrm{~m}^{3} \mathrm{~s}^{-1}\right)$ suggest that the alluvial channel reaches (single thread, braided) generally have higher flow velocities than the downstream anastomosing reaches (Fig. 4). At $1500 \mathrm{~m}^{3} \mathrm{~s}^{-1}$, alluvial reach velocities are typically 1.5 to $2.0 \mathrm{~m} \mathrm{~s}^{-1}$ with anastomosing channel velocities generally between 0.5 and $1.0 \mathrm{~m} \mathrm{~s}^{-1}$. This pattern persists as discharge increases, with alluvial reach velocities exceeding $4.0 \mathrm{~m} \mathrm{~s}^{-1}$ at $5000 \mathrm{~m}^{3} \mathrm{~s}^{-1}$ while anastomosing channel velocities generally remain between 2.5 and $3.5 \mathrm{~m} \mathrm{~s}^{-1}$. This pattern suggests that during moderate floods it is the alluvial reaches that are more susceptible to sediment loss (particularly unconsolidated sandy sediments), rather than the anastomosed reaches where fine sediment (sand, silt) tends accumulate across any islands inundated by the flow. As discharge increases beyond $3500 \mathrm{~m}^{3} \mathrm{~s}^{-1}$, however, the model results suggest that both the alluvial and anastomosed reaches exhibit flow velocities capable of eroding unconsolidated sandy and more cohesive silty sediments, therefore leading to more widespread stripping and high sediment transport rates. 


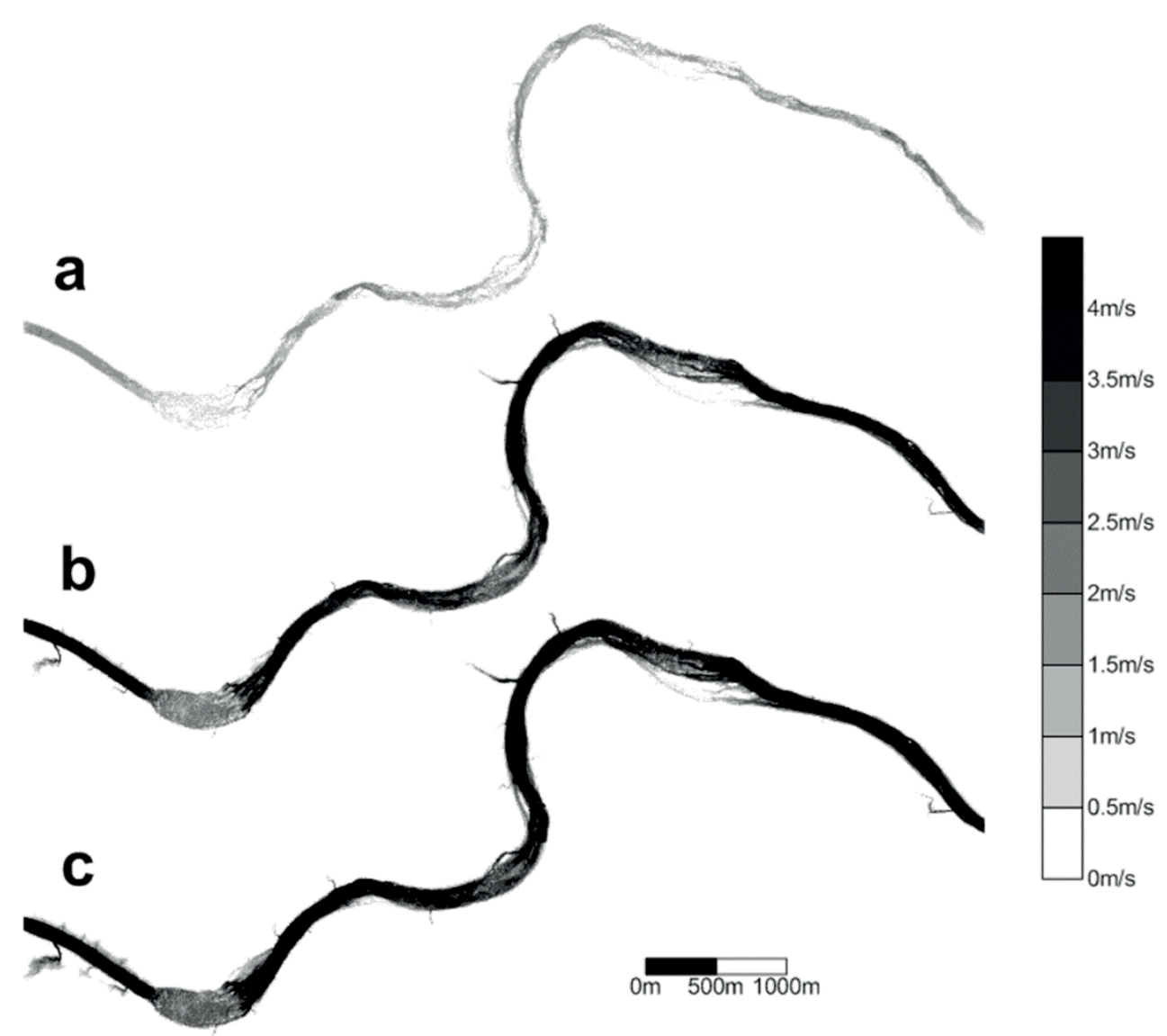

Fig. 4 Simulated flow velocities for an alternating alluvial (single thread, braided) and mixed anastomosing reach of the Sabie River for discharges of 1500,3500 and $5000 \mathrm{~m}^{3} \mathrm{~s}^{-1}$; flow is left to right.

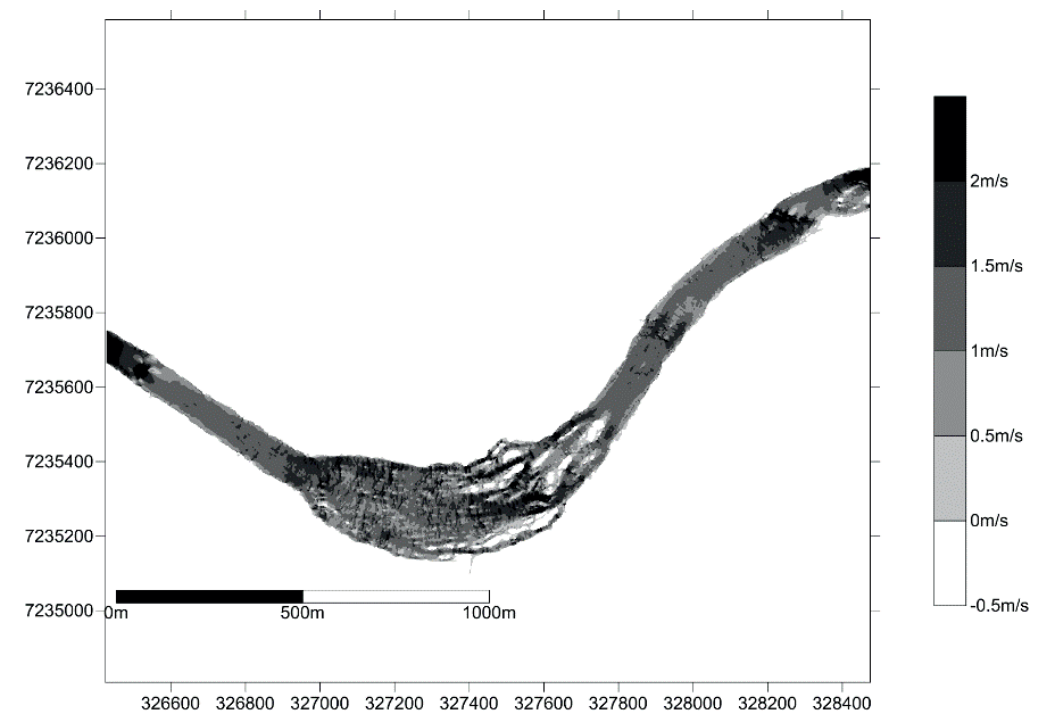

Fig. 5 Simulated flow velocities during a discharge of $500 \mathrm{~m}^{3} \mathrm{~s}^{-1}$ for a mixed anastomosing reach of the Sabie River. More alluviated reaches occur both upstream and downstream; flow is left to right.

The steep gradients generally exhibited by the anastomosed reaches of the Sabie River (Fig. 3), would not seem to be conducive to the existence of long-lived river bottom woodland that nonetheless develops during extended periods of general alluviation (van Coller et al., 2000). However, expansion of the macrochannel in the anastomosed sections means that flood width can be two to three times the width along the more confined alluvial reaches, and this flow expansion 
leads to lower velocities locally, especially at lower discharges. Figure 5 illustrates this for a discharge of $500 \mathrm{~m}^{3} \mathrm{~s}^{-1}$. During periods characterised by a flow regime dominated by low and moderate floods, local low velocity areas in the anastomosed reach would allow cohesive sediments to accumulate over bedrock to form bars and islands, and these tend to remain unimpacted by high flood velocities.

The $500 \mathrm{~m}^{3} \mathrm{~s}^{-1}$ simulation also provides an indication of the conditions likely to occur in the reaches upstream and downstream of anastomosing sections during the falling limb of a more extreme flood (Fig. 5). It is clear that velocities drop significantly upstream and downstream of the anastomosed reach. Such conditions are conducive to the deposition and temporary storage of sediment, thereby replacing any sediment eroded during the preceding flood peak.

\section{CONCLUSIONS}

Two-dimensional hydraulic modelling of the Sabie River allows a number of conclusions to be drawn regarding the morphologic development of this bedrock-influenced semi-arid system. Extreme cyclone-generated floods generate velocities sufficient to erode and transport consolidated and unconsolidated alluvial sediment along the entire river. Such an event occurred in January 2012, leading to the development of a more bedrock-dominated system. It should be noted that the impact of this 2012 flood is likely to have been heightened due to the short recovery period following a similar flood in 2000. Lower magnitude floods, more characteristic of the system during extended alluviating phases, generate conditions capable of eroding and transporting unconsolidated sediment in alluvial reaches. Unconsolidated sandy channel sediments in single thread and braided reaches are particularly susceptible to change, with sedimentary features that are lost to erosion during the rising limb and flood peaks being able to re-form in their former locations as flood levels recede. Consolidated silty sediments (e.g. developing over bedrock-cored islands in anastomosed reaches) are generally not subjected to high velocities during moderate floods, thereby allowing continuing island sedimentation when other reaches are stripped. However, even these island sediments are susceptible to erosion under more extreme flow conditions. These findings suggest that differential stripping (Heritage et al., 2004) operates along the Sabie River, with localised patterns of stripping occurring during periods of long-term general alluviation, and more widespread catastrophic stripping events (Nanson, 1986) being linked to multiple cyclone-driven floods.

Acknowledgements This project was funded through NERC Urgency Grant NE/K001132/1. We would like to thank SANParks for supporting this research by allowing access to the rivers in the Kruger National Park and by providing the 2004 LIDAR data.

\section{REFERENCES}

Cheshire, P. (1994) Geology and geomorphology of the Sabie River, Kruger National Park and its catchment area. CWE Report 1/1994. Heritage GL., Broadhurst LJ. and Birkhead AL. (2001) The influence of contemporary flow regime on the geomorphology of the Sabie River, South Africa. Geomorphology 38(3), 197-211.

Heritage GL., et al. (2003) Estimating extreme flood magnitude in bedrock-influenced channels using representative reachbased channel resistance data. Geografiska Annaler: Series A, Phys. Geog. 85(1), 1-11.

Heritage GL, et al. (2004) Channel hydraulics and geomorphic effects of an extreme flood event on the Sabie River, South Africa. Catena 58(2), 151-181.

Horitt, M.S. and Bates P.D. (2002) Evaluation of 1D and 2D numerical models for predicting river flood inundation. J. Hydrol. 268(1-4), 87-99.

Kale, VS., Baker, VR. and Mishra, S. (1996) Multi-channel patterns of bedrock rivers: an example from the central Narmada basin, India. Catena 26, 85-98.

Nanson, G.C. (1986) Episodes of vertical accretion and catastrophic stripping: a model of disequilibrium floodplain development. Bull. Geol. Soc. Am. 97, 1467-1475.

Rogers, K.H. and O'Keefe, J. (2003) River Heterogeneity: Ecosystem structure, function and management. In: du Toit, J.T, Rogers, K.H. and Biggs, H.C. (eds) The Kruger Experience: Ecology and management of savanna heterogeneity. Island Press, Washington, 59-80.

Tooth S. (2000) Process, form and change in dryland rivers: a review of recent research. Earth-Science Reviews 51, 67-107.

Van Coller, A.L., Rogers, KH. and Heritage, GL. (2000) Riparian vegetation-environment relationships: complementarity of gradients versus patch hierarchy approaches J. Veg. Sci. 11(3), 337-350

Van Niekerk, A.W., Heritage, G.L. and Moon, B.P. (1995) River classification for management: the geomorphology of the Sabie River. South African Geog. J., 77(2), 68-76. 